\title{
THE EFFECT OF PRAZIQUANTEL (DRONCIT) ON CYSTICERCUS PISIFORMIS IN RABBITS
}

\author{
B. KOUDELA, H. SCHANZEL
}

Department of Pathological Morphology and Parasitology, University of Veterinary Science, 61242 Brno

Received February 21, 1978

\begin{abstract}
Koudela B., H. Schanzel: The Effect of Praziquantel (Droncit) on Cysticercus pisiformis in Rabbits. Acta vet. Brno, 47, 1978: 87-90.

Rabbits experimentally infested by Cysticercus pisiformis were treated by different single doses of praziquantel (Droncit-Bayer). The drug was administered orally at successive stages of development of cysticerci. The dosage tested of about 8 and $15 \mathrm{mg} \mathrm{kg}^{-1}$ and no effect on number, size and vitality of cysticerci.
\end{abstract}

Experimental infection, chemotherapy, oral administration.

A new highly efficient cesticidal compound has been developed recently 2-(cyclohexylcarbonyle)$-1,3,4,6,7,11$ b-hexahydro-2H-pyrazino/2,1-a/isoquinolin-4-one, with the following structural formula:<smiles>O=C1CN(OC2CCCCC2)CC2c3ccccc3CCN12</smiles>

The short term for the compound is praziquantel, and the producer, Bayer, delivered it to the market under the name Droncit.

The drug is very well tolerated, as has been shown by Mürmann et al. (1976). In mice and rats, $\mathrm{LD}_{50}$ ranged from 2,000 to $3,000 \mathrm{mg} \mathrm{kg}^{-1}$ after oral administration and was even higher when administered parenterally. The $\mathrm{LD}_{50}$ for dogs could not be determined, since doses from $200 \mathrm{mg} \mathrm{kg}^{-1}$ resulted in vomiting. Praziquantel showed neither skin-sensibilizing nor embryotoxic and teratogenic effects. Andrews (1976) demonstrated very rapid absorption of praziquantel from duodenum and very rapid distribution to organs CNS included. The drug is rapidly metabolized, probably in the liver, and eliminated.

The efficacy of praziquantel on adult tape-worms has been tested mainly in dogs and cats (Güralp et al. 1976; Rommel et al. 1976; Dey-Hazra 1976). Like with other cesticides, largely different doses were needed depending upon the species of tapeworm involved. Dey-Hazra (1976) achieved complete expulsion of Echinococcus granulosus by a single dose of $5.0 \mathrm{mg} \mathrm{kg}$ administered to experimentally and naturally infested dogs. A single dose of $2.5 \mathrm{mg} \mathrm{kg}^{-1}$ was perfectly effective against Dipylidium caninum, $2.0 \mathrm{mg} \mathrm{kg}^{-1}$ against Taenia hydatigena, and, as little as $1.0 \mathrm{mg} \mathrm{kg}^{-1}$ against Taenia pisiformis in dogs and Taenia taeniaeformis in cats. Referring to the fact that field results are usually a little worse than experimental results, the author recommended an uniform dose of $5.0 \mathrm{mg} \mathrm{kg}^{-1}$.

Another matter were the results concerning the effect of praziquantel on larval stages of tapeworms, reported by Thomas et al. (1975a, b, 1977), Thomas and Andrews (1977) Lang- 
nes (1976), Hörchner et al. (1976), Thomas and Gönnert (1976, 1978). Langnes (1976), and Hörchner et al. (1976), observed a very good effect on Cysticercus tenuicollis in pigs and a satisfactory result with Cysticercus pisiformis in experimentally infested rabbits after $50 \mathrm{mg} \mathrm{kg}^{-1}$ for 5 days : $60 \%$ of cysticerci were found dead. They started their treatment 8 weeks after infestation, thus at a time when the cysticerci were settled, developed and surrounded by their protective cuticula. Having in mind the importance of the right moment for chemotherapy emphasized by Hinz (1961, 1964) particularly for measles of the cysticercus type, we decided to investigate whether even lowered doses of praziquantel would not act efficiently as long as the larvae had not finished migration or the cysticerci missed protection by the outer cuticular layer.

\section{Material and Methods}

Rabbits of different breeds, sex ( 9 males and 18 females) and age $(2.5-4.2 \mathrm{~kg}$ ) were infested by administering a ripe proglottis of Taenia pisoformis orally to each animal. At the day of infestation one animal was treated by half a tablet of Droncit, one by a whole tablet, while a third rabbit remained untreated. At intervals of one week, three more rabbits were treated in the same way. The mean doses of praziquantel were $7.82 \pm 0.71 \mathrm{mg} \mathrm{kg}{ }^{-1}$ and $14.86 \pm 2.62 \mathrm{mg} \mathrm{kg}^{-1}$, respectively. After 10 weeks of trial, the rabbits were weighed, killed, dissected and examined for number, size and vitality (microthermal test) of cysticerci. Limits of confidence were calculated for statistical evaluation of results.

\section{Results}

The results are summarized in Table 1:

Table 1

Effect of a single dose of praziquantel on Cysticercus pisiformis in experimentally infested rabbits

\begin{tabular}{|c|c|c|c|c|c|c|}
\hline \multirow{2}{*}{$\begin{array}{l}\text { Treat- } \\
\text { ment } \\
\text { days } \\
\text { p.i. }\end{array}$} & \multicolumn{2}{|c|}{ Group I } & \multicolumn{2}{|c|}{ Group II } & \multicolumn{2}{|c|}{ Group III } \\
\hline & $\begin{array}{c}\text { dose } \\
\mathbf{m g} / \mathbf{k g}\end{array}$ & $\begin{array}{c}\text { No. of } \\
\text { cysticerci }\end{array}$ & $\begin{array}{l}\text { dose } \\
\mathrm{mg} / \mathbf{k g}\end{array}$ & $\begin{array}{c}\text { No. of } \\
\text { measles }\end{array}$ & $\begin{array}{c}\text { dose } \\
\mathbf{m g} / \mathbf{k g}\end{array}$ & $\begin{array}{c}\text { No. of } \\
\text { cysticerci }\end{array}$ \\
\hline $\begin{array}{r}0 \\
7 \\
14 \\
21 \\
28 \\
35 \\
42 \\
49 \\
56\end{array}$ & $\begin{array}{l}9.6 \\
8.8 \\
8.7 \\
7.4 \\
7.3 \\
6.7 \\
7.2 \\
7.2 \\
7.5\end{array}$ & $\begin{array}{r}76 \\
12 \\
2 \\
4 \\
9 \\
3 \\
2 \\
6 \\
11\end{array}$ & $\begin{array}{l}17.2 \\
22.8 \\
15.6 \\
12.5 \\
12.0 \\
12.8 \\
13.8 \\
12.8 \\
14.3\end{array}$ & $\begin{array}{r}1 \\
112 \\
9 \\
16 \\
3 \\
8 \\
4 \\
4 \\
1\end{array}$ & $\begin{array}{l}- \\
= \\
- \\
- \\
= \\
= \\
-\end{array}$ & $\begin{array}{r}11 \\
7 \\
26 \\
2 \\
64 \\
2 \\
4 \\
9 \\
3\end{array}$ \\
\hline$\pm \begin{array}{c}\bar{x} \\
s_{\bar{x}} \cdot t\end{array}$ & $\begin{array}{r}7.82 \\
\pm \mathbf{0 . 7 1}\end{array}$ & $\begin{array}{r}13.9 \\
+18.1\end{array}$ & $\begin{array}{r}14.86 \\
\pm 2.62\end{array}$ & $\begin{array}{r}17.9 \\
\pm 27.3\end{array}$ & - & $\begin{array}{r}14.2 \\
\pm 15.5\end{array}$ \\
\hline
\end{tabular}

It is obvious that there was no significant difference between the three groups. At no stage of larval development the tapeworm was affected by praziquantel. The cysticerci were equal in size and vitality in both treated and control animals. No side effects were observed.

\section{Discussion}

The negative result of our trial is in accordance with the findings reported by Hörchner et al. (1976). Though they consider oral administration as less effective than the parenteral way, we do not assume the failure of our treatment was due to the oral way of administration we used. Pharmacokinetical studies performed by Andrews (1976), demonstrated that praziquantel is equally efficient after oral and parenteral administration. 
Neither location and structure of the cysticerci is likely to respond for the failure of treatment. Hörchner et al. (1976), who described a very good effect of praziquantel on $C$. fasciolaris in mice and C. tenuicollis in pigs, met no satisfactory result with $C$. pisiformis in rabbits. They concluded that the effect depends rather upon the host species than upon the species of tapeworm.

Compared with our dosage, the doses used by Langnes (1976), and Hörchner et al. (1976), were considerably higher. They administered $50 \mathrm{mg} \mathrm{kg}^{-1}$ for 5 consecutive days and even $100 \mathrm{mg} \mathrm{kg}^{-1}$ for 14 days. On the other hand, they treated rabbits not earlier than 8 weeks after infestation, while in our trial praziquantel was administered at different and earlier stages of larval development. Though Thomas and Gönnert (1978), observed in mice that developed larval stages of $C$. fasciolaris were susceptible to praziquantel while younger stages were not, we feel a new trial would be appropriate, with doses of praziquantel as high and/or repeated as Langnes (1976) and Hörchnes et al. (1976) used, but with a timetable and sequence of treatment described in our report.

\section{Účinek praziquantelu (Droncitu) na Cysticercus pisiformis u králíkủ}

Praziquantel (Droncit-Bayer) se aplikoval v různých dávkách králíkům, experimentálně invadovaným Cysticercus pisiformis. Jednorázová orální dávka kolem $8 \mathrm{mg} / \mathrm{kg}$ a $15 \mathrm{mg} / \mathrm{kg}$ se podávala za rủznou dobu po invazi. Při těchto dávkách se neprojevil žádný účinek na počet, velikost a životnost boubelů.

V literatuře byl popsán $60 \%$ účinek praziquantelu na Cyticercus pisiformis po dávce $50 \mathrm{mg} / \mathrm{kg}$, podávané po 5 dní, a aplikované za 8 týdnủ po invazi králíků.

Soudíme, že $\mathrm{v}$ přištím pokuse bude nutno vyzkoušet vy̌šší, prýípadně opakované dávky praziquantelu, avšak $\mathrm{v}$ časovém sledu, který jsme dodržovali $\mathrm{v}$ této práci.

\section{Воздействие празиквантела (Дронцита) на Cysticercus pisiformis у кроликов}

Празиквантел (Droncit-Bayer) применяли в различных дозах кроликам, әкспериментально зараженным Cysticercus pisiformis. Однократная доза через рот около 8 мг/кг и 15 мг/кг применялась по истечении различного времени после инвазии. Эти дозы не оказывали никакого воздействия на количество, величину и выживание цистицерков.

В литературе указывается $60 \%$ воздействие празиквантела на Cysticercus pisiformis после 5-дневного применения дозы 50 мг/кг, которое производили через 8 недель после инвазии кроликов.

Мы полагаем, что в следующих опытах испытаниям подлежат более высокие и м. б. повторяющиеся дозы празиквантела, однако, в той же временной последовательности, которая соблюдалась в нами предлагаемой работе.

\section{References}

ANDREWS, P.: Pharmakokinetische Tieruntersuchungen mit Droncit unter Verwendung einer biologischen Prüfmethode. Veterinärmedizinische Nachrichten 2, 1976, 154-165.

DEY-HAZRA, A.: The efficacy of Droncit (Praziquantel) against Tapeworm Infection in Dog and Cat. Veterinary Medical Rewiew 2, 1976, 131-141.

GÚRALP, N. - TICIN, Y. - OGUZ, T. - TINAR, R. - BURGU, A.: Vorläufige Untersuchungen über die Wirksamkeit von Droncit gegen verschiedene Bandwurmarten bei Hunden und Katzen. Veterinärmedizinische Nachrichten 2, 1976, 129-133.

HINZ, E.: Chemotherapeutische Untersuchungen an der experimentellen Zystizerkose der Ratte, 
hervorgerufen durch Strobilocercus (Cysticercus) fasciolaris. Z. Tropenmed. Parasit. 72, 1961, $430-437$.

HINZ, E.: Chemotherapeutische Untersuchungen mit Endoxan an der experimentellen Finneninfektion der weissen Maus. Z. Tropenmed. Parasit. 15, 1964, 332-336.

HÖRCHERT, F. - LANGNES, A. - OGUZ, T.: Die Wirkung von Mebendazole und Praziquantel auf larvale Taenienstadien bei Maus, Kaninchen und Schwein. Z. Tropenmed. Parasit. 28, 1976, 44-50.

LANGNES, A.: Zur Chemotherapie von Cysticercus tenuicollis und Cysticercus pisiformis bei Schwein und Kaninchen. Inaug. Diss Berlin 1976.

MÚRMANN, P. - EBERSTEIN, M. von, - FROHBERG, H.: Zur Verträglichkeit von Droncit. Veterinärmedizinische Nachrichten 2, 1976, 142-153.

ROMMEL, M. - GRELCK, H. - HÖRCHNER, F.: Zur Wirksamkeit von Praziquantel in experimentell infizierten Hunden und Katzen. Berl. Münch. Tierärztl. Wschr. 89, 1976, 255 bis 257.

THOMAS, H. - GÖNNERT, R. - POHLKE, R. - SEUBERT, J.: Experimental and clinical studies with a new compound against tapeworms. 7th Int. Conf. on Pathophysiol. of Parasitic Infections, Thessaloniki 1975.

THOMAS, H. - GÖNNERT, R. - POHLKE, R. - SEUBERT, J.: Experiences with a new compound against larval cestodes. 2nd Europ. Multicolloquy of Parasit., Trogir, 1975.

THOMAS, H. - ANDREWS, P.: Praziquantel - A New Cestocide. Pestic. Sci. 8, 1977, 556 to 560.

THOMAS, H. - GÖNNERT, R.: The Efficacy of Praziquantel Against Cestodes in Animals. Z. Parasitenkd. 52, 1977, 117-127.

THOMAS, H. - GÖNNERT, R.: Zur Wirksamkeit von Praziquantel bei der experimentellen Cysticercose und Hydatidose. Z. Parasitenkd. 1978 (in press). 